\title{
Experimental Investigation on the Performance of a CI Engine Fueled with Waste Cooking Oil Biodiesel Blends
}

\author{
Lochan Kendra Devkota, Surya Prasad Adhikari* \\ Department of Mechanical and Aerospace Engineering, Institute of Engineering, Pulchowk Campus, Nepal
}

Corresponding Author: spadhikari@pcampus.edu.np

Received on: $15^{\text {th }}$, Feb., 2021

Accepted for publication: $28^{\text {th }}$ Feb., 2021

\begin{abstract}
In this study, different performance parameters of a Compression Ignition (CI) engine fueled with waste cooking oil biodiesel blends with diesel in different percentage volumes of $5 \%$ biodiesel and $95 \%$ diesel (W5), $10 \%$ biodiesel and $90 \%$ diesel (W10), $15 \%$ biodiesel and $85 \%$ diesel (W15) and $20 \%$ biodiesel and $80 \%$ diesel (W20) were tested experimentally. First, biodiesel was produced from waste cooking oil by transesterification process. The physical-chemical properties of biodiesel and W20 were tested. The tested properties of W20 were found to American Society for Testing and Materials (ASTM) standards near to diesel fuel. Subsequently, test of diesel and biodiesel blended fuels were carried out using 15:1 compression ratio on Kirloskar Single Cylinder Compression Ignition Engine at $1500 \mathrm{rpm}$ on varying loads. The engine performance parameters for biodiesel blends such as Indicated Power (IP), Brake Power (BP), Brake Mean Effective Pressure (BMEP), Brake Thermal Efficiency (BTE), Specific Fuel Consumption (SFC) and Mechanical Efficiency (ME) against load in comparison to diesel fuel were obtained and verified those with diesel fuel. IP for diesel, W5, W10, W15 and W20 at load of $12 \mathrm{~kg}$ are $4.3 \mathrm{~kW}, 4.8 \mathrm{~kW}, 4.7 \mathrm{~kW}, 4.75 \mathrm{~kW}$ and 4.2 $\mathrm{kW}$ respectively. ME of W20 at $12 \mathrm{~kg}$ load is less by $4.1 \%$ than diesel. The difference in SFC of diesel and W20 at $12 \mathrm{~kg}$ load was $0.27 \mathrm{~kg} / \mathrm{kWh}$. The experimental outcomes confirm that the IP and SFC of blended biodiesel were slightly superior. Correspondingly, BP and BMEP were also found comparable to diesel fuel.
\end{abstract}

Keywords: Diesel Engine, Waste Cooking Oil, Engine Performance, Blended Biodiesel.

\section{Introduction:}

Reviewing the research paper as indicated in references, the direct use of vegetable oils in diesel engine lead to different problems like incomplete combustion, poor atomization and fuel filter clocking. Such problems arises due to high viscosity and high density of vegetable oil $[1,2]$. The density and viscosities of the blends increased with the increase of biodiesel concentration in the fuel blend as the density and viscosity of biodiesel is more than diesel [3, 4]. On the other hand, direct use of vegetable oil as biodiesel are the concerns that biodiesel feedstock may compete with food supply in long term [5]. Hence, recent studies are concerned with waste cooking oil (WCO) which also reduces the requirement of disposal for it. Pyrolysis, blending frying oils, micro-emulsion and transesterification are the different techniques to reduce the viscosity of vegetable oil [6-9]. Among all the process, the most 
convenient method is transesterification process. This process makes physical-chemical properties of vegetable oil closely similar to petrodiesel by reducing the viscosity. Transesterification process is relatively straight forward though additional cost is involved because of chemical reaction. Additionally, in transesterification reaction, triglycerides of oil reacts with alcohol in presence of catalyst to give fatty acid or ethyl esters which may be directly burned in unmodified diesel engines, with very low deposit formation [9-11].<smiles></smiles>

Triglyceride (oil)<smiles>[R]C(=O)OCCCC(CO)O[CH+]C</smiles>

Methanol
Glycerol

Figure 1: Transesterification reaction

Leung D.et.al compared the Transesterification reaction conditions for used frying oil and fresh canola oil. When compared to fresh canola oil according to his research, less reaction time was observed for used frying oil than fresh canola oil reaction time [12]. Another experimental research revealed that the engine performance with esters and diesel-vegetable oil blends were comparable to that of diesel operation [13]. Meheret et. al studied the effects of catalyst concentration of Sodium Hydroxide $(\mathrm{KOH})$, alcohol /oil molar ratio, temperature and rate of mixing on the transesterification of Karanja oil with methanol. They found that the optimum reaction conditions for methanolysis of Karanja oil was $1 \% \mathrm{KOH}$ as a catalyst, molar ratio 6:1, reaction temperature $650{ }^{\circ} \mathrm{C}$, rate of mixing was $360 \mathrm{rpm}$. Finally their results revealed that the alkaline catalyzed transesterification as the promising method for the production of fuel quality biodiesel [14]. Based on those above mentions research, transesterification process was chosen for the production of biodiesel from WCO. Therefore, the main aim of this research is to prepare the biodiesel from WCO via transesterification process and investigate the engine performance of WCO biodiesel blends.

\section{Experimental Methods and Materials:}

\subsection{Preparation of Biodiesel:}

For Transesterification reaction, first of all, waste cooking oil was filtered by using filtering clothes to remove those impurities and was heated up to temperature of $60{ }^{\circ} \mathrm{C}$ which is measured by mercury thermometer. $\mathrm{KOH}$ and methanol mixture was added slowly to oil stirring at $300 \mathrm{rpm}$ by magnetic stirrer. The amount of $\mathrm{KOH}$ used was $1.5 \%$ of oil weight and amount of methanol to oil used was in the molar ration of $6: 1$. The temperature was maintained at $60{ }^{\circ} \mathrm{C}$ during stirring by heat block using oil bath. After the sufficient reaction time of about 90 minutes, heating and stirring is stopped. About 10 minutes later, two layers were seen. The upper layer is biodiesel and the lower layer in black color is glycerine which was removed by using separating funnel. The biodiesel after separating glycerin is washed with distilled water until the PH Value of sample was 7 which were checked by $\mathrm{PH}$ paper to remove the other impurities like methanol, soap and ionic impurities that are dissolved in methyl esters. The biodiesel yield was found to be 94.67 $\%$ which was calculated by dividing amount of biodiesel formed by the amount of waste cooking oil initially taken.

\subsection{Preparation of Blends:}

Methyl esters, the final product of transesterification reaction by $20 \%$ of volume and diesel by $80 \%$ of volume was mixed by measuring with measuring cylinder for characterization of biodiesel blends. 


\subsection{Thermo-physical Properties Test of Blended Biodiesel Fuel:}

W20 Biodiesel blend was sent to Fare lab, Delhi, India for finding different physical-chemical properties of Fuel. The tested properties were calorific value, density, kinematic viscosity, pour point and flash point.

\subsection{Fourier Transform Infrared (FT-IR) Test:}

FTIR test was done by an FT-IR spectrometer in Department of plant, Thapathali, Kathmadu for finding out the functional group that are present in biodiesel blend and diesel to compare the type of functional group present in them.

\subsection{Engine Specifications:}

The engine under test was Kirloskar diesel engine available in Thapathali Campus, Thapathali, Kathmandu. The technical specifications of test engine are shown in Table 1. Similarly, the engine is shown in Fig. 2.

Table 1: Engine Test Rig Specifications

\begin{tabular}{|c|c|c|}
\hline S.No. & Features & Specifications \\
\hline 1 & Make & $\begin{array}{l}\text { Kirloskar Diesel } \\
\text { Engine }\end{array}$ \\
\hline 2 & Type & $\begin{array}{l}\text { Four stroke, Water } \\
\text { cooled Diesel }\end{array}$ \\
\hline 3 & $\begin{array}{l}\text { Number of } \\
\text { cylinder }\end{array}$ & 1 \\
\hline 4 & $\begin{array}{l}\text { Combustion } \\
\text { principle }\end{array}$ & Compression ignition \\
\hline 5 & Maximum speed & $1500 \mathrm{rpm}$ \\
\hline 6 & Crank radius & $55 \mathrm{~mm}$ \\
\hline 7 & Compression ratio & $15: 1$ \\
\hline 8 & Loading & $\begin{array}{l}\text { Eddy current } \\
\text { dynamometer }\end{array}$ \\
\hline 9 & Maximum power & $3.5 \mathrm{~kW}$ \\
\hline 10 & $\begin{array}{c}\text { Connecting Rod } \\
\text { length }\end{array}$ & $300 \mathrm{~mm}$ \\
\hline 11 & Method of starting & $\begin{array}{l}\text { Electric motor } \\
\text { cranking }\end{array}$ \\
\hline
\end{tabular}

\subsection{Experimental Test Procedure:}

Initially the test engine was tested at a steady speed of $1500 \mathrm{rpm}$ with diesel fuel about 15 to 20 minutes for attaining stable working environment. It is important to note that the coolant i.e. water is circulated in the engine at a pressure of nearly $1 \mathrm{~atm}$, which can be read by the pressure gauge setup in the engine. After that, engine was run with different as-prepared WCO biodiesel blends. During the test, engine was loaded with 1-12 (in $\mathrm{kg}$ ) at an interval of 3 kg i.e. $1 \mathrm{~kg}, 3 \mathrm{~kg}, 6 \mathrm{~kg}, 9 \mathrm{~kg}$ and $12 \mathrm{~kg}$ using an eddy current dynamometer maintaining constant speed of $1500 \mathrm{rpm}$ and the required engine performance data for different blends were taken. Similarly, same procedure was followed for diesel fuel and the required data were taken. The rate of flow of biodiesel fuel is measured using a burette and stop watch setup in the engine where fuel consumed during $60 \mathrm{sec}$ time is noted.

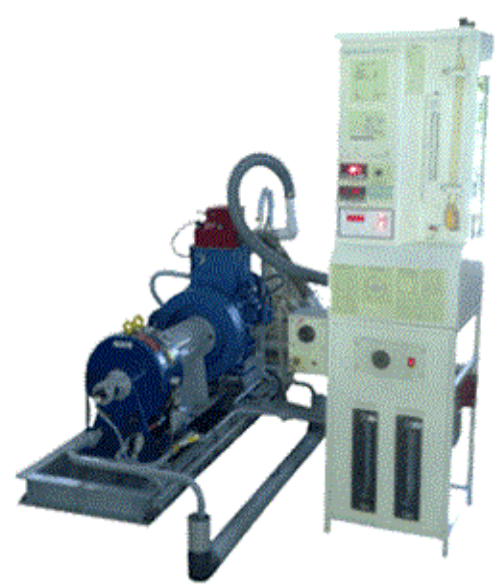

Figure 2: Test Engine

\section{Result and Discussion:}

\subsection{Thermo-physical Properties of Fuel:}

The blended biodiesel prepared in the lab was tested as per the test method of ASTM D1298 standard for density, ASTM D2382 standard for calorific value, ASTM D445 standard for kinematic viscosity, ASTM D3828 standard for flash point and ASTM D97 standard for pour point. The results of the test conducted are shown in Table 2. The obtained numerical values of those physical-chemical properties of blended fuel were comparable to diesel.

Table 2: Properties of W20 and Diesel

\begin{tabular}{|c|c|c|c|}
\hline Properties & W20 & Diesel & $\begin{array}{c}\text { Test } \\
\text { Method }\end{array}$ \\
\hline $\begin{array}{c}\text { Density at } 15^{\circ} \mathrm{C}, \\
\mathrm{kg} / \mathrm{m}^{3}\end{array}$ & 841 & 830 & $\begin{array}{l}\text { ASTM } \\
\text { D1298 }\end{array}$ \\
\hline $\begin{array}{c}\text { Calorific value, } \\
\mathrm{KJ} / \mathrm{kg}\end{array}$ & 39711 & 43200 & $\begin{array}{l}\text { ASTM } \\
\text { D2382 }\end{array}$ \\
\hline $\begin{array}{c}\text { Kinematic } \\
\text { viscosity at } 40 \\
{ }^{\circ} \mathrm{C}, \mathrm{Cst}\end{array}$ & 2.161 & $1.9-4.1$ & $\begin{array}{l}\text { ASTM } \\
\text { D445 }\end{array}$ \\
\hline $\begin{array}{l}\text { Flash Point } \\
\text { (Minimum), }{ }^{\circ} \mathrm{C}\end{array}$ & 47 & 52 & $\begin{array}{l}\text { ASTM } \\
\text { D3828 }\end{array}$ \\
\hline Pour Point, ${ }^{\circ} \mathrm{C}$ & -9 & -11 & $\begin{array}{l}\text { ASTM } \\
\text { D97 }\end{array}$ \\
\hline
\end{tabular}




\subsection{FT-IR Analysis:}

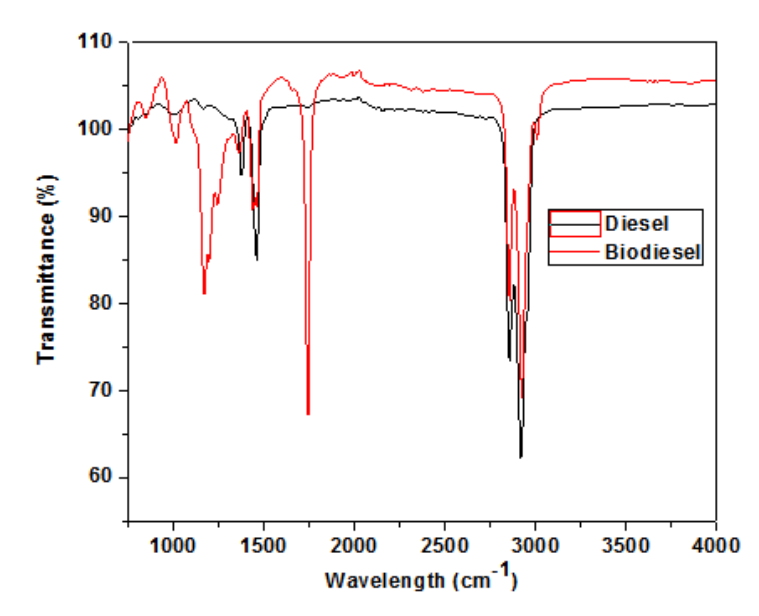

Figure 3: FTIR Result

Figure 3 demonstrates the FTIR spectrum of the diesel and biodiesel. The peak around $1195 \mathrm{~cm}^{-1}$ of biodiesel indicates $\mathrm{C}-\mathrm{O} / \mathrm{O}-\mathrm{CH}_{3}$ is associated to ester group. Similarly, another sharp peak of biodiesel around $1745 \mathrm{~cm}^{-1}$ indicates $\mathrm{C}=\mathrm{O}$ of stretching vibration, which is allocated to a esters groups [15]. The similar peaks of both biodiesel and diesel found around $1450 \mathrm{~cm}^{-1}$ region corresponds to typical stretching mode of $\mathrm{O}-\mathrm{CH}_{3}$, which is related to methyl ester group. Consequently, some strong peaks of both found in the range of $2800-2950 \mathrm{~cm}^{-1}$ correspond to typical stretching mode of $\mathrm{CH}_{2}$ group which is associated to alkane groups $[15,16]$. Thus, it can be confirmed that both biodiesel and conventional diesel have the same functional group of $\mathrm{C}-\mathrm{H}$. On the other hand, the conventional diesel had no oxygen group, whereas biodiesel showed oxygen functional group such as $\mathrm{C}-\mathrm{O}$ around $1745 \mathrm{~cm}^{-1}$. Thus, conventional diesel without $\mathrm{C}=\mathrm{O}$ group produced more black smoke in comparison to diesel due to the incomplete combustion while the biodiesel with the presence of oxygen promotes cleaner and complete combustion.

\subsection{Engine Performance Results:}

Figure 4 illustrates that IP increases with load in diesel and all waste cooking oil blends. It shows that the indicated power is the higher for all blended biodiesels at all loading conditions compared to pure diesel fuel. Among those, W5, W10 and W15 show comparatively higher power in all loads and smooth increment in power with load. This increased IP for blended biodiesel may be due the higher oxygen content i.e. $\mathrm{C}=\mathrm{O}$ as a functional group and better spray due to the lower viscosity of biodiesel in comparison to the diesel fuel. These verdicts are in accordance with Adaileh WM et.al. and Nileshkumar KD et.al. [17, 18].

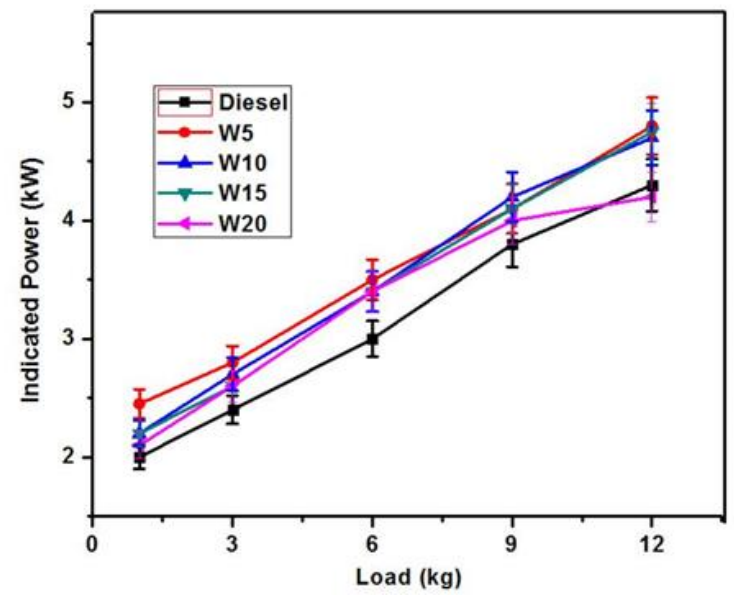

Figure 4: Indicated Power Vs Load

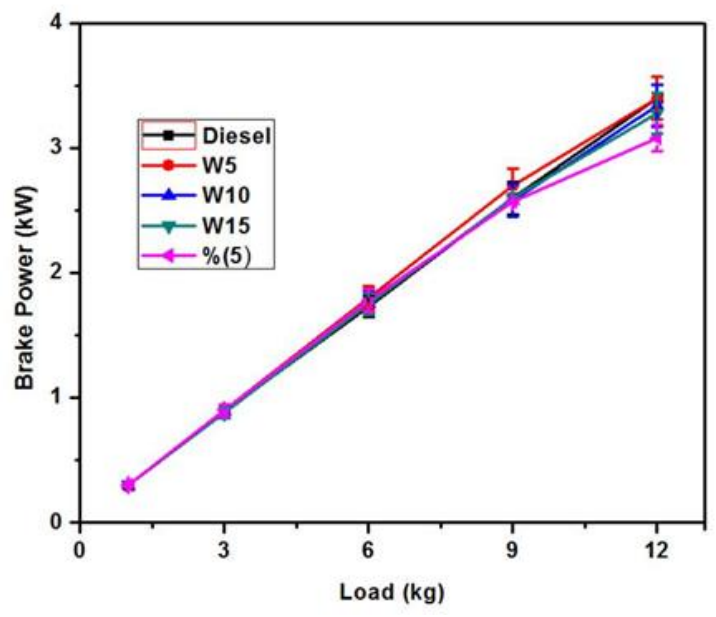

Figure 5: Brake Power Vs Load

Figure 5 illustrates the variation of BP with load for diesel and all waste cooking oil blends. The value of BP increases with increase in load in all cases both for blend and diesel. The increment of BP is almost similar for diesel and biodiesel. BP for W10, W15 and W20 were less than diesel by $0.06 \mathrm{~kW}, 0.12 \mathrm{~kW}$ and $0.32 \mathrm{~kW}$ at highest load whereas W5 shows exactly the same BP of $3.4 \mathrm{~kW}$ as diesel.

The variation of BMEP for diesel and waste cooking oil blends is illustrated in Fig. 6. In all cases BMEP increases with increase in load. Waste cooking oil blends shows similar BMEP at all loading condition compared with diesel 
fuel. BMEP for diesel and W20 at $12 \mathrm{~kg}$ load was 4.13 bar and 4.15 bar which was almost similar.

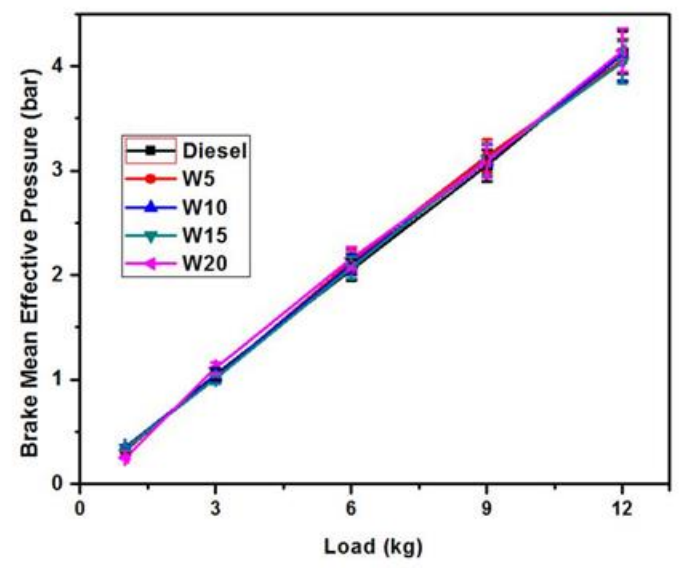

Figure 6: Brake Mean Effective Pressure Vs Load

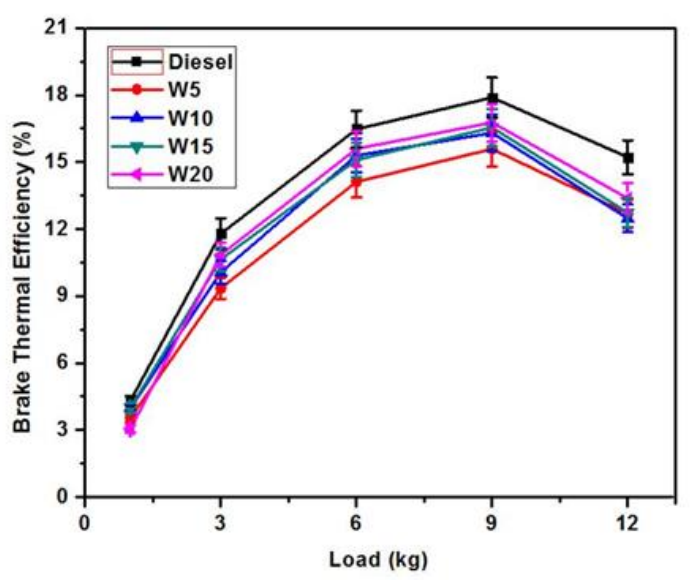

Figure 7: Brake Thermal Efficiency Vs Load

BTE is the indication of how effectively the fuel is converted into mechanical output. The BTE for biodiesel blends and diesel fuel increases up to certain load. This can be recognized to decrease in heat loss and increase in power with increase in load. All blended fuel has lower BTE at all load in comparison to diesel. This was due to the lower calorific value and poor combustion characteristics in comparison to diesel. These finding are in accordance with K.A. Abed et.al. on a Kirloskar make, single cylinder, four strokes, and direct injection diesel engine fuelled with WCO blends [19]. Among all those blended fuel, W15 and W20 shows higher BTE. Maximum BTE at $9 \mathrm{~kg}$ load for W20 and diesel was $17 \%$ and $18 \%$, respectively.

The variation of SFC with different loading condition for diesel fuel and waste cooking oil blends is presented in Fig. 8. Specific fuel consumption decreases on increasing load up to $9 \mathrm{~kg}$ for all the blend and diesel. After $9 \mathrm{~kg}$, SFC increases. SFC for the biodiesel blend is higher for all the blends than diesel in all loads. It was because of low calorific value of biodiesel than diesel [16]. These results are in accordance with M Chiba et.al [20]. The higher the biodiesel blend content in blended fuel results in lower heating value, results in higher SFC. SFC for W20 and diesel at $9 \mathrm{~kg}$ load is $0.58 \mathrm{~kg} / \mathrm{kWh}$ and $0.43 \mathrm{~kg} / \mathrm{kWh}$, respectively.

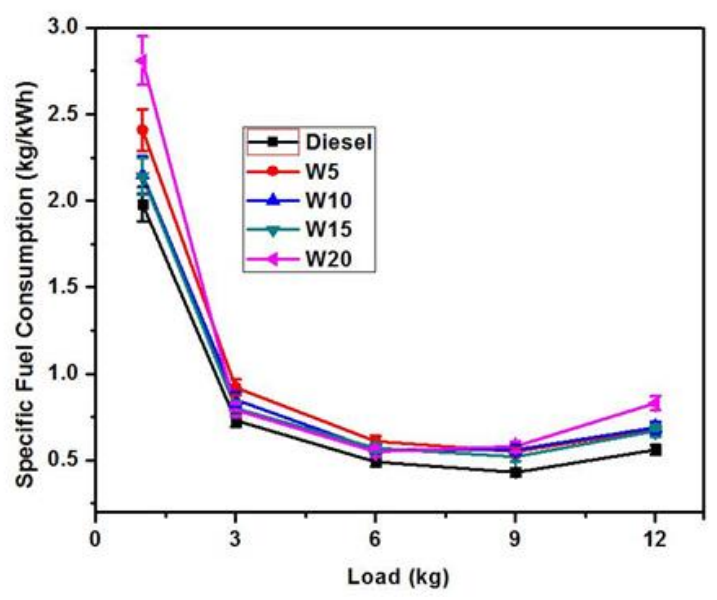

Figure 8: Specific Fuel Consumption Vs Load

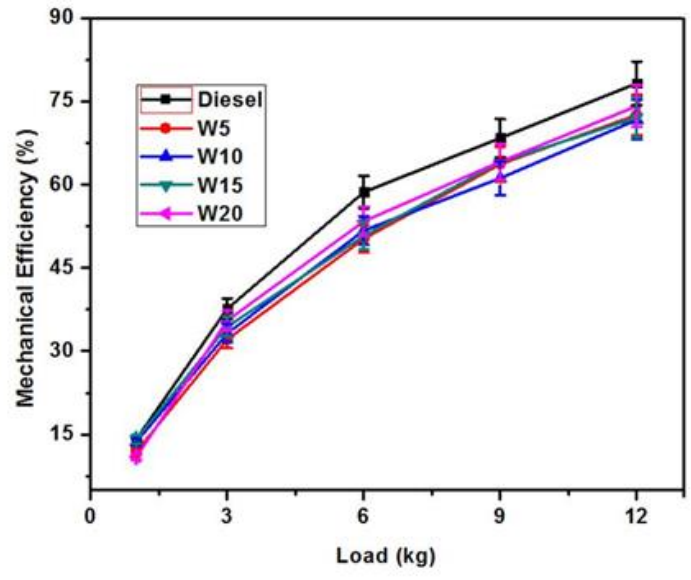

Figure 9: Mechanical efficiency Vs Load

Mechanical efficiency shows how much the power developed by fuel is actually delivered as useful power. Figure 9 demonstrates mechanical efficiency for all the blends and diesel increases as the load increases. Since brake power increases on increasing load, mechanical efficiency also increases with increasing brake power for the entire blend. It can be seen that mechanical efficiency for W20 is better than 
other blends. These results are in accordance with the Nileshkumar KD et.al. who illustrated that the mechanical efficiency of biodiesel blends increased with blend proportion [18]. The difference is mechanical efficiency at $12 \mathrm{~kg}$ load for diesel and W20 was $4.1 \%$.

\section{Conclusion:}

The physical- chemical properties of biodiesel were comparable to diesel. Presence of $\mathrm{C}=\mathrm{O}$ in biodiesel helps in complete combustion which is advantage over diesel. The IP and SFC of all blended biodiesel were obtained slightly higher than diesel. Consequently, BP and BMEP of all

\section{References:}

[1] Nagaraja S, Sooryaprakash K, Sudhakaran R. Investigate the Effect of Compression Ratio Over the Performance and Emission Characteristics of Variable Compression Ratio Engine Fueled with Preheated Palm Oil - Diesel Blends. Procedia Earth and Planetary Science 2015;11:393-401.

[2] as R, Jayaraj S, Chandrasekharan M. Use of vegetable oils as I.C. engine fuels - A review. Renewable Energy 2004;29:727-42.

[3] Alptekin E, Canakci M. Determination of the density and the viscosities of biodiesel-diesel fuel blends. Renewable Energy 2008;33:2623-30.

[4] Khan MB, Kazim AH, Shabbir A, Farooq M, Farooq H, Ali Q, et al. Performance and emission analysis of high purity biodiesel blends in diesel engine. Advances in Mechanical Engineering

2020;12:1687814020974156.

[5] Balat M. Potential alternatives to edible oils for biodiesel production - A review of current work. Energy Conversion and Management 2011;52:1479-92.

[6] Demirbaş A. New liquid biofuels from vegetable oils via catalytic pyrolysis. Energy Edu Sci Technol 2008;21:1-59. biodiesel were also found comparable to diesel fuel. However, Mechanical efficiency and BTE of blended biodiesel were found slightly lower than diesel fuel. Thus, from above obtained results, it can be concluded that biodiesel from waste cooking can be a good alternative source of energy that can replace fossils fuels as a clean energy source.

\section{Acknowledgements:}

We would like to thank the Department of Automobile and Mechanical Engineering, Thapathali campus for providing the necessary lab facilities.

[7] Debnath S, Vidyarthi S, Singh R. Impact of blending of frying oils on viscosity and heat transfer coefficient at elevated temperatures. Journal of Food Process Engineering 2009;33:144-61.

[8] Santos ICVM, Martelloti RR, Oliveira PF, Mansur CRE. Development of microemulsions to reduce the viscocity of crude oil emulsions. Fuel 2017;210:684-94.

[9] Schuchardt U, Sercheli R, Vargas RM. Transesterification of vegetable oils: a review. Journal of the Brazilian Chemical Society 1998;9:199-210.

[10] Refaat AA. Different techniques for the production of biodiesel from waste vegetable oil. International Journal of Environmental Science \& Technology 2010;7:183-213.

[11] Math M, Chandrashekhara K. Optimization of Alkali Catalyzed Transesterification of Safflower Oil for Production of Biodiesel. Journal of Engineering 2016;2016:1-7.

[12] Leung D, Guo Y. Transesterification of neat and used frying oil: Optimization for biodiesel production. Fuel Processing Technology 2006;87:883-90.

[13] Srithar K, Arun Balasubramanian K, Pavendan V, Ashok Kumar B. Experimental investigations on mixing of two biodiesels blended with diesel as alternative fuel for diesel engines. 
Journal of King Saud University Engineering Sciences 2017;29:50-6.

[14] Meher Lc, Naik S, Das L. Methanolysis of Pongamia pinnata (karanja) oil for production of biodiesel. Journal of Scientific \& Industrial Research 2004;63:913-8.

[15] Lamichhane G, Khadka S, Koirala N, Adhikari S, Poudyal D. Biofuel Production from Waste Cooking Oils and Its Physicochemical Properties in Comparison to Petrodiesel2019.

[16] Popovicheva OB, Kireeva ED, Shonija NK, Vojtisek-Lom M, Schwarz J. FTIR analysis of surface functionalities on particulate matter produced by off-road diesel engines operating on diesel and biofuel. Environmental Science and Pollution Research 2015;22:4534-44.

[17] Adaileh WM, AlQdah KS. Performance of Diesel Engine Fuelled by a Biodiesel Extracted From A Waste Cocking Oil. Energy Procedia 2012;18:1317-34.
[18] Nileshkumar KD, Jani R, Patel $T$, Rathod GP. Effect of blend ratio of plastic pyrolysis oil and diesel fuel on the performance of single cylinder CI engine. IJSTE - Int J Sci Technol Eng 2015;1:2349-784.

[19] Abed KA, El Morsi AK, Sayed MM, Shaib AAE, Gad MS. Effect of waste cooking-oil biodiesel on performance and exhaust emissions of a diesel engine. Egyptian Journal of Petroleum 2018;27:985-9.

[20] Islam MS, Ahmed AS, Islam A, Abdul Aziz S, Xian LC, Mridha M. Study on Emission and Performance of Diesel Engine Using Castor Biodiesel. Journal of Chemistry 2014;2014:451526. Jha, P.C.; Jha, R. Course Manual on Irrigation and Drainage Engineering. Tribhuvan Uiversity, Institute of Engineering, Pulchowk Campus, Department of Civil Engineering, Water Resources Instruction Committee, 2059. 